\title{
Application of Herzegovinian dolomite as dimension stone
}

\author{
Krešimir Šaravanja \\ Ministry of Construction and Physical Planning of HNC and Faculty of Civil Engineering, \\ University of Mostar, Ph.D C.E., kresimir.saravanja@gf.sum.ba \\ Frano Oreč \\ Association "Sound of Stone" Posušje, B.Sc.(Mining), frano.orec@zvukkamena.com
}

Ante Karačić

ADJ2 gradnja d.o.o. Mostar, M.Eng.C.E., antekaracic22@gmail.com

\begin{abstract}
In the first part of this paper the occurrence of dolomite in B\&H karst, as well as active and potential dolomite deposits for dimension stone with different trade names ("Rujan" , "San", "Gradac") are presented, with the available results of their testing. The final section of the paper gives a brief historical overview of the applications of dolomite as dimension stone in Herzegovina, which is attested by many tombstones, but also some religious and residential buildings. However, with its beauty of textures and colors and quality in workmanship, in the last several decades it has been widely used in the interior and exterior cladding of numerous buildings in Herzegovina, as well as in several regional architectural projects along the Adriatic coast, in the Republic of Croatia and Republic of Montenegro. The final section of the paper provides relevant conclusions related to the application of dolomite as dimension stone.
\end{abstract}

Key words: dimension stone, cut stone, Herzegovina (Region), dolomite, dolomite breccia, "Rujan", "San", "Gradac", "Rhodolite", stone testing, IGH-Mostar

\section{Primjena hercegovačkih dolomita kao arhitektonsko- građevnog kamena}

Sažetak: U prvom dijelu rada je prikazana zastupljenost dolomita u b-h kršu, kao i aktivna i potencijalna ležišta dolomita za AGK raznih trgovačkih naziva („Rujan“, „San“, „Gradac“), s raspoloživim rezultatima njihovih ispitivanja. U završnom dijelu rada dan je kratak povijesni osvrt na primjene dolomita kao AGK u Hercegovini, o čemu svjedoče mnogi nadgrobni spomenici, ali i neke vjerske, te stambene građevine. Zadnjih par desetljeća, svojom ljepotom tekstura i boja, te kvalitetom u izradi, dolomit je dosta korišten u unutarnjem i vanjskom oblaganju brojnih objekata u Hercegovini, kao i na nekoliko regionalnih projekata arhitekture duž jadranske obale, u Republici Hrvatskoj i Republici Crnoj Gori. U završnom dijelu rada dani su odgovarajući zaključci vezani za primjenu dolomita kao AGK.

Ključne riječi: arhitektonsko-građevni kamen, prirodni kamen, Hercegovina, dolomit, dolomitna breča, „Rujan“, „San“, „Gradac“, „Rodolit“, ispitivanje kamena, IGH-Mostar 
Šaravanja, K., Oreč, F., Karačić, A.

Application of Herzegovinian dolomite as dimension stone

\section{INTRODUCTION}

The conventional way of using stone as a structural (load-bearing) material is mostly abandoned, and dimension stone is used as a decorative and protective element of different buildings, most commonly in the form of tiles, plates and elements of different sections for exterior and interior cladding of load-bearing structures built of other materials. The development of the stone extraction and cutting technology makes them more affordable and available in the market. Modern stone cutting machines make it possible to design the most complex surfaces, plates of desired shapes, dimensions and methods of surface treatment.

The region of Herzegovina is rich in the dimension stone production resources, with a long tradition in production. Tectonic conditions in the zone of the so-called "high karst" resulted in a high degree of fracturing of the rock mass, which makes it difficult to extract competent commercial stone blocks suitable for industrial cutting, so the block sizes, labor costs and rising extraction costs are the main reasons for the closure of many quarries in recent decades. Today, the extraction of smaller blocks increases the available reserves, and the stone is used more rationally.

Dolomites are carbonate rocks that occur in all geological periods, more in older geological formations, most often in the Mesozoic.2,17 They are formed in several ways: mechanically (by cementation of transported particles of weathered dolomitic rocks), by chemical precipitation (sedimentation of dolomite minerals from oversaturated solutions), and (most often) by the process of "dolomitization", or metasomatism of limestone. Magnesium ions from groundwater replace calcium ions in the crystal lattice of calcite. Depending on whether the replacement is complete or partial, the transition forms range from limestone $(0$ $9 \%$ dolomite mineral), to dolomitic (magnesium) limestone (10-49\% dolomite), calcitic (calcareous) dolomite (50-89\% dolomite), to (pure) dolomite (90-100\% dolomite). ${ }^{2,16,17}$

Dolomite deposits can be very thick-bedded, massive in texture and gray in color, but they can also be weathered deposits, prone to decomposition or formation of grus, and are often used as borrow pits for construction materials. ${ }^{9}$ They are made of fine and medium grained white or ashy gray dolomite with cracks and very thin joints, so they are sometimes fractured on the surface. The proportions of individual components of $\mathrm{Ca}$ and $\mathrm{Mg}$ are different and quite variable. Sometimes they have a brecciated structure.

\section{DEPOSITS OF HERZEGOVINIAN DIMENSION STONE DOLOMITE}

The application of dolomite as dimension stone is not as wide and significant as with limestone, while when used as technical stone it even has some advantages (better grain shape when crushing, better wear resistance). ${ }^{2}$

The occurrence of dolomites in the Bosnian-Herzegovinian karst is significantly lower than of limestones together with which they mostly occur. They are often interconnected by transitional types (dolomitic limestones and calcitic dolomites). They extend mostly in the border belt between the Outer and Inner Dinarides (Konjic, Jablanica, Prozor, Kupres, Bugojno, Jajce, source of Sana, Bosanski Petrovac, Drvar, Bosansko Grahovo). As already mentioned, most of them have Mesozoic, specifically Triassic age. ${ }^{1}$

According to Zogović (1966), dolomite rocks play a very significant hydrogeological role in the Dinarides karst. ${ }^{1}$

Dolomites and dolomitic limestones from the transition from the Lower to the Upper Cretaceous $\left(\mathrm{K}_{1,2}\right)$, extending mainly in the NW-SE direction, are identified in several places in the West Herzegovina. The boundary between Alb-Cenomanian dolomites and Lower Cretaceous limestones with orbitolines is gradual, as is the boundary towards overlying 
Šaravanja, K., Oreč, F., Karačić, A.

Application of Herzegovinian dolomite as dimension stone

deposits with chondrodonts. In the wider area of Herzegovina, they occur in narrower zones in anticline crests, except in the area of Peć Mlini, where they occur on larger areas. ${ }^{9}$

Apart from Peć Mlini, significant potential locations are in the area of Ljubotic and Gradac. $^{9}$

In the Posušje municipality, dolomites occur in the area of the southern slope of the Radovanj mountain above the village of Rastovača. They are present in the village of Broćanac, from Širića Draga to the border of the City of Široki Brijeg, and in the village of Gradac. At these sites they have been used for hundreds of years for structures. ${ }^{14}$

"Gradac" is the trade name for gray Lower Cretaceous dolomitized limestone and dolomitized breccias, which are very decorative. The company "Ukraskamen" from Posušje has long extracted the stones Gradac A, B and C in three colors, originating from deposits near Posušje. ${ }^{13}$
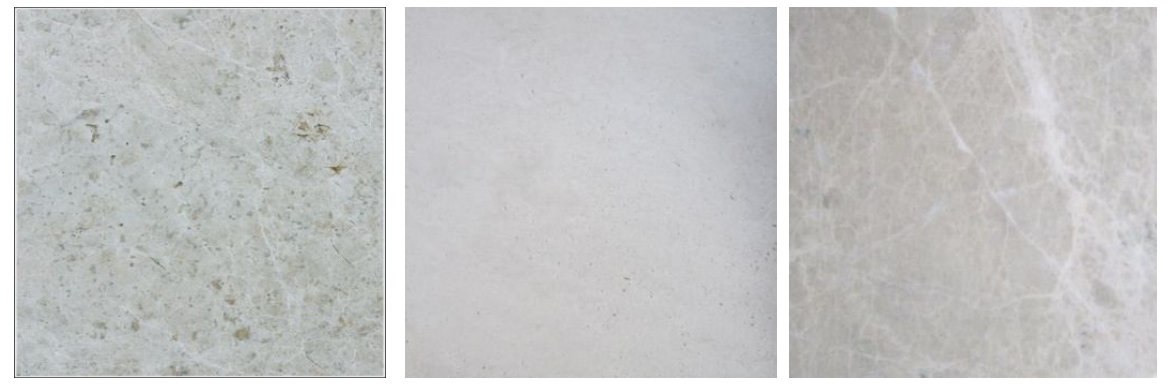

Figures 1-3. Dolomite "Gradac" (left); Triassic dolomite "Rhodolite", Šupljika, Jablanica (middle); ${ }^{6}$ Saccharoid dolomite (right) ${ }^{4}$

"Rujan" is the trade name for dolomite of Cretaceous age from the deposits between Kočerin near Široki Brijeg and Vranić near Posušje. It is classified as microcrystalline dolomite, and from the microscopic analysis it can be seen that it was formed by dolomitization of organogenic limestone, from which relics are left behind in some places, due to which it often has the appearance of dolomitic breccia. It is gray in color, of medium compressive strength and wear resistance. It is used for covering vertical and low-traffic horizontal surfaces. The quarry of massive dolomites at the Osoje - Dubint site, the City of Široki Brijeg, is active, and it operates the extraction of dolomite breccia. ${ }^{13,9,14,17}$

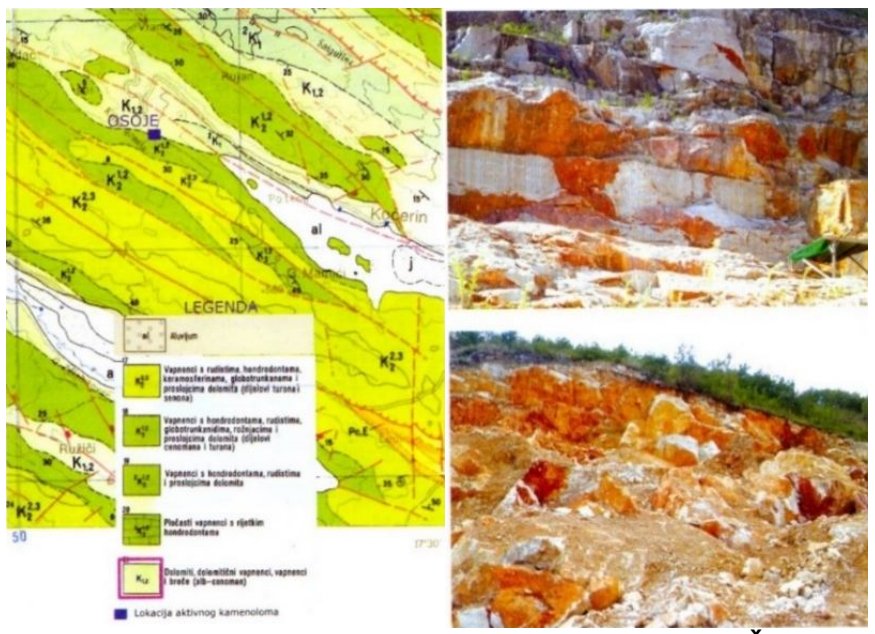

Figures 4-5. Active dolomite quarry Osoje - Dubint, Široki Brijeg:

Excerpt from Basic Geological Map (BGM), Imotski sheet (left); Photos of the quarry (right) ${ }^{9}$ 
Šaravanja, K., Oreč, F., Karačić, A.

Application of Herzegovinian dolomite as dimension stone

About two $\mathrm{km}$ from the Osoje quarry, in Ivankovića Dolac, there is a plant for stone processing and production of stone products: floor tiles of various finishes and formats, staircases, window sills, copings and thresholds, stone for facade cladding, skirting, broken mosaic of non-standard dimensions and others products at the request of customers.
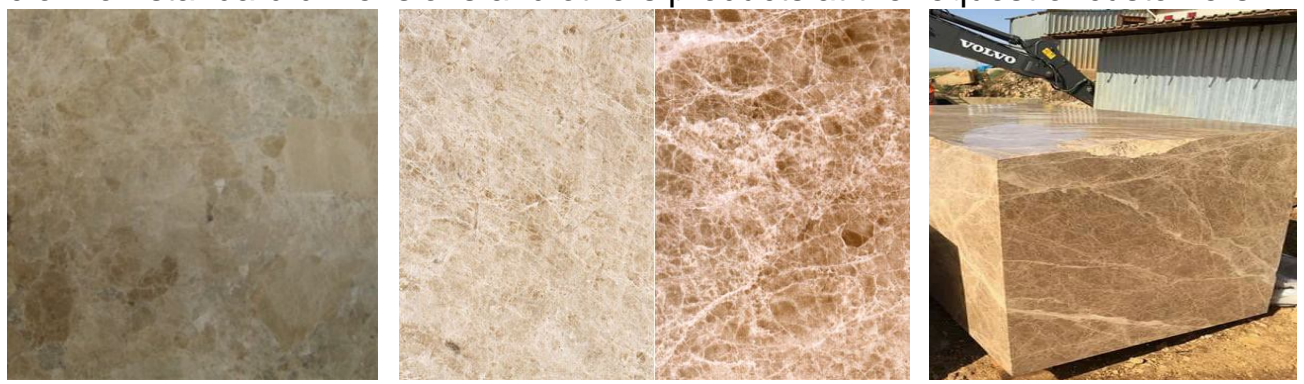

Figures 6-8. Stone "Rujan" - Osoje, Ivankovića Dolac, Široki Brijeg (left); "Rujan" polished light and dark (middle); Dolomite block "Rujan" (right) ${ }^{6}$

Based on BGM, Imotski sheet, it was determined that the wider area of the San deposit, NW of Crne Lokve, $17 \mathrm{~km}$ from the City of Široki Brijeg, is built of various rocks of stratigraphic range from the Lower Cretaceous to the Quaternary. The area of the "San" dimension stone study space and its immediate surroundings is built of Upper Cretaceous carbonates, limestones and dolomites of the Turonian - Cenomanian $\left(\mathrm{K}_{2}{ }^{2,3}\right)$. Thick-bedded massive late diagenetic dolomites represent a mineral raw material, or dimension stone, of very good characteristics. ${ }^{11}$

The stone sample of the commercial name "San" was found to be fine saccharoid dolomite according to the results of microscopic and macroscopic examinations (mineral composition, structural and textural properties), fine crystalline dolomite according to Folk, and crystalline carbonate rock according to Dunham. ${ }^{11}$

The deposit is located in massive late diagenetic (post-sedimentary or secondary) dolomites of the Turonian - Cenomanian stratigraphic association. Layered micrites are predominantly found in the underlying strata, and light gray, white to light pink brecciated limestones in the overlying strata. ${ }^{11}$

Dolomite with the commercial name "San" is suitable for external and internal vertical cladding, for external and internal paving for very busy pedestrian areas, as well as for the production of boss, sculptures and all stone-masonry elements. ${ }^{14}$
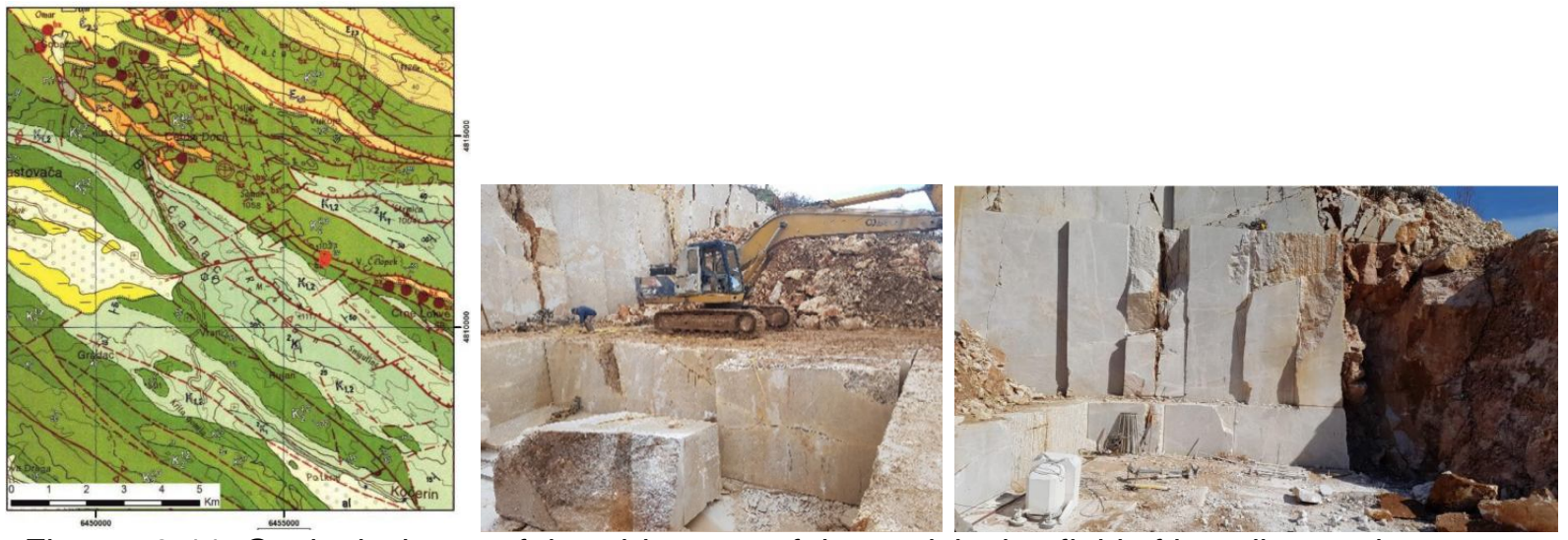

Figures 9-11. Geological map of the wider area of the exploitation field of late diagenetic dolomite "San" (Raić et al., 1967) (left); ${ }^{11}$ Open-pit mine San-Crne Lokve, City of Široki Brijeg (middle and right) $)^{4,11}$ 
Šaravanja, K., Oreč, F., Karačić, A.

Application of Herzegovinian dolomite as dimension stone

The location of the Cretaceous dolomite Ljubotići, $15 \mathrm{~km} \mathrm{NW}$ of the City of Široki Brijeg, probably is not really representative of dimension stone. However, considering that dolomite extends over a larger area, there are probably also high-quality blocks within this locality. ${ }^{9,14}$

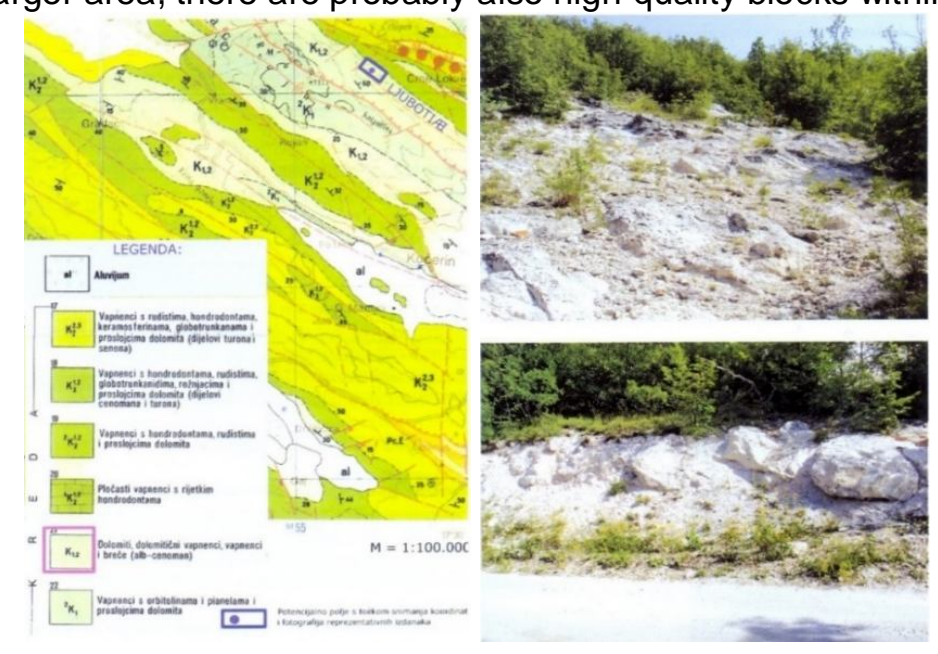

Figures 12-13. Potential field Ljubotići, Široki Brijeg: Excerpt from BGM, Imotski sheet (left); Photographs of representative outcrops (right) ${ }^{9}$

\section{RESULTS OF TESTING THE QUALITY OF DOLOMITE AS DIMENSION STONE}

Dolomite is a rock of milky white color, and from impurities like limestone they can be differently colored, so they are often light gray to grayish in color, and other shades of color appear irregularly in some places, especially in the near-surface parts of the rock mass. As the depth of the deposit increases, the color shades are more uniform. ${ }^{11,16}$

Table 1. Test results for dolomite stone "Rujan", "San" and "Gradac"1,4,11,13,14,20,21

\begin{tabular}{|c|c|c|c|c|c|c|c|c|c|c|}
\hline \multicolumn{2}{|c|}{ Tested property } & MU & \multicolumn{5}{|c|}{ Rujan $4,13,14,20,21$} & \multicolumn{2}{|c|}{ San $^{4,11}$} & Gradac \\
\hline \multicolumn{2}{|c|}{ Density (specific gravity) } & $\mathrm{kg} / \mathrm{m}^{3}$ & 2,770 & - & 2,797 & 2,854 & 2,770 & 2,795 & - & - \\
\hline \multicolumn{2}{|c|}{ Bulk density } & $\mathrm{kg} / \mathrm{m}^{3}$ & 2,690 & $2,670^{*}$ & 2,742 & 2,795 & 2,690 & 2,735 & 2,735 & 2,740 \\
\hline \multicolumn{2}{|l|}{ Porosity } & $\%$ & 2.89 & - & 1.98 & $1.7 / 2.1$ & - & - & - & 3.90 \\
\hline \multirow{2}{*}{$\begin{array}{l}\text { Water } \\
\text { absorption }\end{array}$} & $\begin{array}{l}\text { under atm. } \\
\text { pressure }\end{array}$ & \multirow[t]{2}{*}{$\%$} & 1.16 & \multirow[t]{2}{*}{$1.4^{* *}$} & 0.54 & 0.6 & 1.12 & 0.52 & - & 0.72 \\
\hline & by cooking & & 1.12 & & 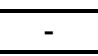 & - & - & - & - & - \\
\hline \multirow{3}{*}{$\begin{array}{l}\text { Compres- } \\
\text { sive } \\
\text { strength }\end{array}$} & in dry state & $\mathrm{MPa}$ & - & - & 175.8 & 167.0 & \multirow{3}{*}{$\begin{array}{l}134.0 . . \\
247.0\end{array}$} & \multirow{3}{*}{$\begin{aligned} 128.0 . . \\
164.0\end{aligned}$} & 152.1 & 152.0 \\
\hline & in WS state & $\mathrm{MPa}$ & - & - & 171.8 & 154.0 & & & - & - \\
\hline & $\begin{array}{l}25 \text { freezing } \\
\text { cycles }\end{array}$ & $\mathrm{MPa}$ & - & - & - & - & & & - & - \\
\hline \multirow{2}{*}{$\begin{array}{l}\text { Flexural } \\
\text { strength }\end{array}$} & in dry state & $\mathrm{MPa}$ & - & - & 14.6 & 13.5 & - & \multirow{2}{*}{$\begin{array}{c}22.0 \ldots \\
30.0\end{array}$} & 26.2 & 10.5 \\
\hline & in WS state & $\mathrm{MPa}$ & - & - & - & 11.6 & - & & - & - \\
\hline \multicolumn{2}{|c|}{$\begin{array}{l}\text { Fracture resistance around } \\
\text { the anchor dowel hole }\end{array}$} & $\mathrm{kN}$ & - & - & - & - & - & $\begin{array}{c}10.0 \ldots \\
12.0\end{array}$ & - & - \\
\hline \multicolumn{2}{|c|}{$\begin{array}{l}\text { Resistance according to } \\
\text { Böhme }\end{array}$} & $\mathrm{cm}^{3}$ & 19.0 & $25.0^{*}$ & 17.4 & 16.884 & 19.0 & 18.3 & - & 27.0 \\
\hline \multicolumn{2}{|c|}{ Frost resistance } & - & resist. & - & - & - & resist. & resist. & - & - \\
\hline \multicolumn{2}{|c|}{ Frost resistance $\left(\mathrm{Na}_{2} \mathrm{SO}_{4}\right)$} & - & $0.5 \%$ & - & - & 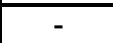 & & - & - & - \\
\hline
\end{tabular}

${ }^{\text {* }}$ Rujan marked $\mathrm{H} ;{ }^{* *}$ Rujan marked $\mathrm{U}$ 
Šaravanja, K., Oreč, F., Karačić, A.

Application of Herzegovinian dolomite as dimension stone

Taking a general view, the test results of compressive strength of dolomite are in a wide range from 140 to $260 \mathrm{MPa}$, density $2,800-2,900 \mathrm{~kg} / \mathrm{m}^{3}$, bulk density $2,700-2,840 \mathrm{~kg} / \mathrm{m}^{3}$, porosity $0.8-5.0 \%$ of volume, and water absorption $0.5-3.0 \%$ of weight. ${ }^{16}$

In the last couple of decades, a certain number of dolomite samples was tested in "IGHMostar" d.o.o. Mostar, while the stone "Gradac" was tested in "IGH" d.d. Zagreb.

The results show a significant scatter of test results, which is understandable because the obtained results depend on the representativeness of the tested samples, and Table 1 shows three different dolomite stones and nine incomplete tests.

In general, dolomite is a stone of medium high/ high compressive strength, with low water absorption, low porous. By bulk density, it is a heavy stone, and by wear resistance it is a hard stone, but also moderately hard in some cases. All this should be taken into account when using these dolomites.

The structure of dolomites depends on the way they are formed and the amount of $\mathrm{CaCO}_{3} \mathrm{component}$ in them. It is usually fine-crystalline and saccharoid (when grains can be distinguished by the eye). ${ }^{16}$

Table 2. Mineralogical-petrographic analysis of the stone "Rujan" Ivankovića Dolac (Mineralogical-petrographic institute of the Faculty of Science, Zagreb, 2000) ${ }^{20}$ and the stone "San", San-Crne Lokve (2012) ${ }^{11}$

\begin{tabular}{|c|c|c|}
\hline & "Rujan"20 & "San"11 \\
\hline $\begin{array}{l}\text { Macro- } \\
\text { scopic } \\
\text { descrip- } \\
\text { tion }\end{array}$ & $\begin{array}{l}\text { gray stone, of spotty } \\
\text { appearance (lighter and darker } \\
\text { gray parts), uneven scaly } \\
\text { fracture surfaces. The reaction } \\
\text { with dilute } \mathrm{HCl} \text { is weak and } \\
\text { only associated with the } \\
\text { material in cracks. Thus, it is a } \\
\text { dolomite intersected by fine } \\
\text { calcitic veins. The spotty } \\
\text { appearance is most likely due } \\
\text { to different degrees of } \\
\text { dolomitization and } \\
\text { recrystallization of individual } \\
\text { parts. }\end{array}$ & $\begin{array}{l}\text { Stone color: very pale orange to pinkish gray and gray-pink } \\
\text { with sparse black inclusions. } \\
\text { Fracture: Sharp and irregular; fracture plane surfaces are } \\
\text { uneven and medium to finely rough, and slightly glittering } \\
\text { from cleavage surfaces of fine crystals of carbonate mineral. } \\
\text { Stone hardness: approximately } 4 \text { (according to Mohs). } \\
\text { Stone texture: homogeneous with sparse cracks and light- } \\
\text { colored veins. } \\
\text { Structure: markedly microcrystalline. Under the magnifying } \\
\text { glass we observe a crystalline structure, fine irregular grains } \\
\text { of carbonate minerals, then rare small fractures filled with } \\
\text { sparite-sized crystals, and cleavage surfaces. No detritus is } \\
\text { observed. } \\
\text { Reaction with } \mathrm{HCl}(10 \%) \text { : Very weak, with substantial delay } \\
\text { Field determination: Dolomite of crystalline structure (Cx). }\end{array}$ \\
\hline $\begin{array}{l}\text { Micro- } \\
\text { scopic } \\
\text { descrip- } \\
\text { tion }\end{array}$ & $\begin{array}{l}\text { dolosparite structure with } \\
\text { anhedral (irregular) small } \\
\text { dolomitic crystals. Remains of } \\
\text { unaltered limestone clasts of } \\
\text { micritic structure and micro- } \\
\text { sparite relics of primary, most } \\
\text { likely micritic particles, } \\
\text { destroyed by recrystallization } \\
\text { and dolomitization, can be } \\
\text { seen in some places. } \\
\text { Considering the larger } \\
\text { crystalline structure and the } \\
\text { destructive character of } \\
\text { dolomitization - it is a late } \\
\text { diagenetic dolomite }\end{array}$ & $\begin{array}{l}\text { In the microscopic specimen, in the transmitted light of the } \\
\text { microscope, it is possible to see aggregate of approximately } \\
\text { non-uniform sections of dolomite mineral crystals, } \\
\text { homogeneous texture, and rare millimeter cracks, which are } \\
\text { less often filled with sparite-sized calcite. The mineral } \\
\text { composition is dolomite, calcite and opaque mineral. The } \\
\text { dominant mineral ingredient is the mineral dolomite, of which } \\
\text { approximately close to } 100 \% \text { is present. It is found as crystal } \\
\text { grains of different sections: irregular, isometric, polygonal and } \\
\text { rhomboid of sparite size, which get deeply into each other. } \\
\text { There is very little calcite and it is found as irregular sparite- } \\
\text { sized sections, within dolomite crystals and along some } \\
\text { cracks. In some we observe pressure twin lamellae, and in } \\
\text { some two systems of cleavage cracks }\end{array}$ \\
\hline $\begin{array}{l}\text { Conclu- } \\
\text { sion }\end{array}$ & $\begin{array}{l}\text { Dolomite - of dolosparite } \\
\text { structure, intersected by } \\
\text { calcite veins and with rare } \\
\text { remains of unaltered limestone } \\
\text { clasts }\end{array}$ & $\begin{array}{l}\text { Fine saccharoid dolomite, according to Folk - fine crystalline } \\
\text { dolomite, and according to Dunham - crystalline carbonate } \\
\text { rock }\end{array}$ \\
\hline
\end{tabular}


Šaravanja, K., Oreč, F., Karačić, A.

Application of Herzegovinian dolomite as dimension stone

In many properties dolomites are similar to limestones, but they are also different from them in some properties - lower water solubility, higher density, higher hardness and the ability to break into cubical pieces. When weathering into very small grains of a rhombohedron shape with sharp edges (dolomite sand) that are in contact only by their surfaces, the rock is easily weathered along these surfaces. They are usually grainy in appearance, sometimes quite coarse-grained..$^{2,16,17}$

\section{APPLICATION OF HERZEGOVINIAN DOLOMITE AS DIMENSION STONE}

Dolomites are very rarely used as dimension stone because they do not have a wide range of colors and patterns like limestones (fossil remains in dolomites are usually absent), and they do not have the ability to take on high gloss by polishing as in compact limestones. ${ }^{2}$

Nevertheless, dolomite stone has been extracted in these areas since ancient times, which is borne out by many tombstones in the oldest cemeteries, whose state of preservation and durability are evidence of its usability and quality. An excellent example is the Kočerin plate, a tombstone from the $15^{\text {th }}$ century, whose state of preservation of the text is indicative of the durability and quality of local stone. ${ }^{8}$
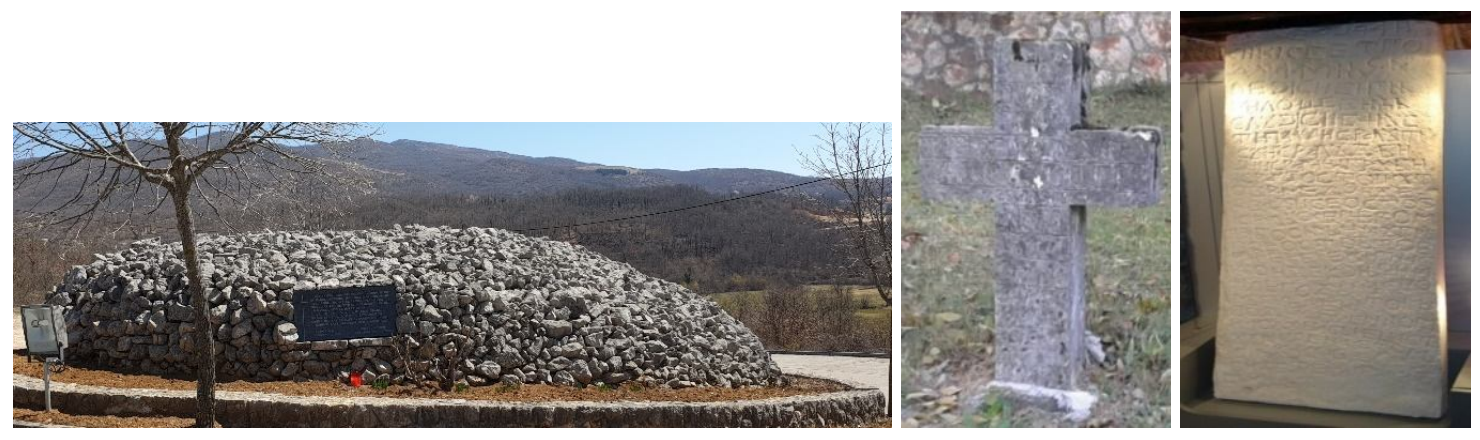

Figures 14-16. Illyrian hill-fort, built of native dolomite stone (breccia) (left; photo: K. Šaravanja); Stone cross (middle) ${ }^{8}$ Kočerin plate (right) ${ }^{8}$

Analyzing stone buildings in the Municipality of Posušje, Frano Oreč found that dolomites were built into numerous buildings in the area of the settlements of Broćanac and part of Gradac (eastern part). The parish church of Gradac was built in the late $19^{\text {th }}$ century of chiseled indigenous stone breccia of the Upper Cretaceous, and isolated blocks of dolomite can be observed. ${ }^{8}$

The Church of the Assumption of the Blessed Virgin Mary (ABVM) in Široki Brijeg was built of blocks of monoliths and quasi-monoliths of Upper Cretaceous limestones, dolomitic limestones, limestone dolomites, and materials from layer contacts, breccias and conglomerates. The materials were extracted near the church. ${ }^{7}$ As part of the interior, the cross vaults above the side naves were built of dolomite, as was a decorative detail of floor covering of the "Rujan" stone in the church floor. ${ }^{17}$ 
Šaravanja, K., Oreč, F., Karačić, A.

Application of Herzegovinian dolomite as dimension stone
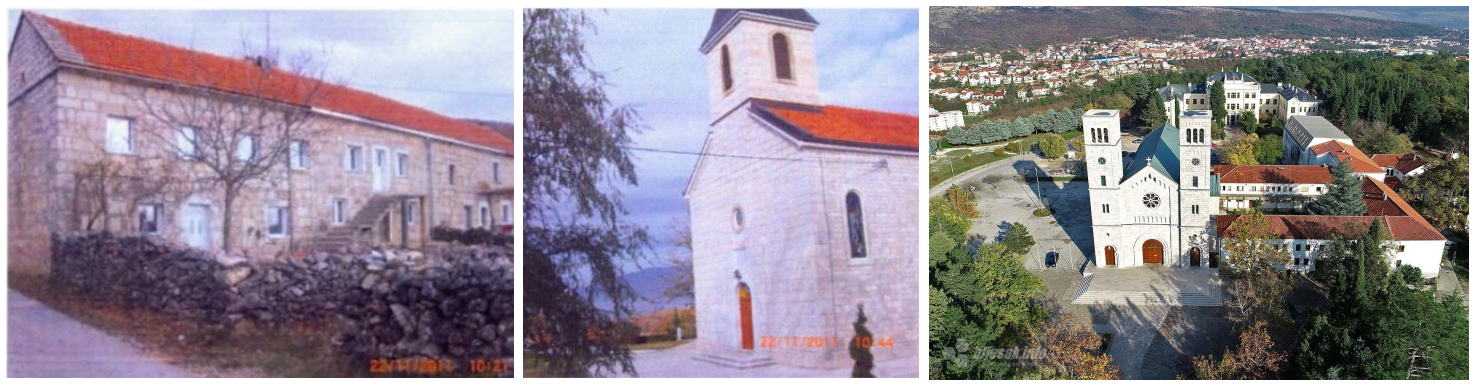

Figures 17-19. House in the hamlet of Knezovići (Širića Brig) in Posušje, built 80-100 years ago from chiseled local dolomite (left; photo: F. Oreč); 8 Parish Church Gradac, built in the late $19^{\text {th }}$ century from chiseled stone breccia of the Upper Cretaceous, with isolated dolomite blocks (middle; photo: F. Oreč); ${ }^{8}$ Church ABVM in Široki Brijeg (right, photo: bljesak.info)

Due to its decorativeness, the "Rujan" stone is in great demand in the market. The dolomitic breccia of favorable toughness, good workability and polish, with a range of colors from a gentle beige to a darker shade, gives it charm and warmth that is especially appreciated and recognized by the architectural profession.
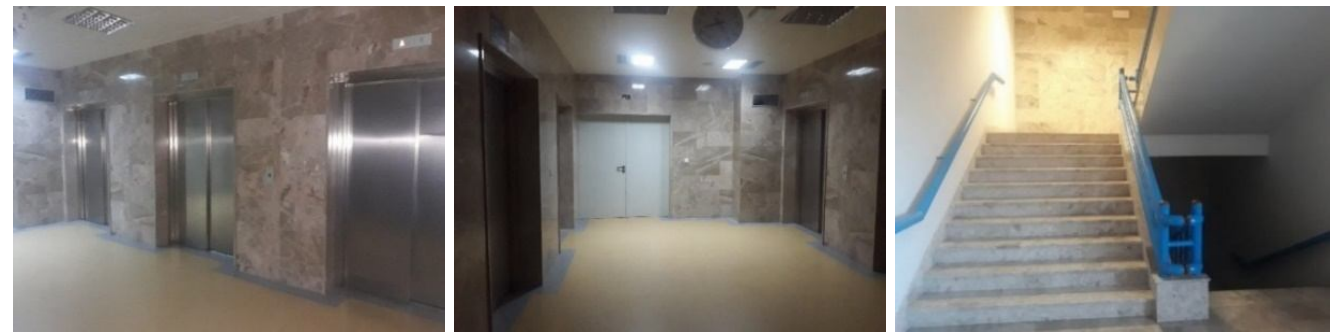

Figure 20-22. Stone "Rujan" at the University Clinical Hospital Mostar (Photo: A. Karačić, $2019)^{6}$
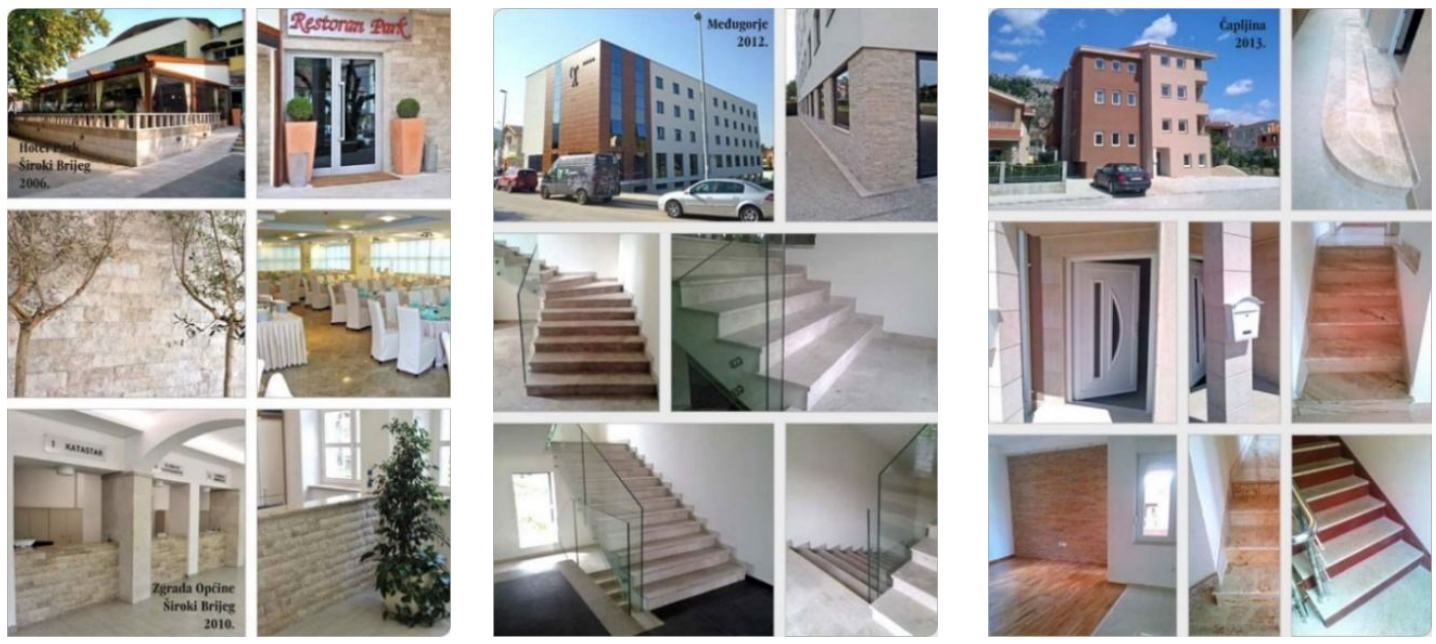

Figures 23-25. Examples of installation of the "Rujan" stone in buildings in Široki Brijeg (2006-2010; left), in Medjugorje, Čitluk (2012; middle) and in Čapljina (2013; right) ${ }^{6}$ 
Šaravanja, K., Oreč, F., Karačić, A.

Application of Herzegovinian dolomite as dimension stone

Despite its continental origin and suitable installation sites, the "Rujan" stone has been applied to several projects along the Adriatic coast.
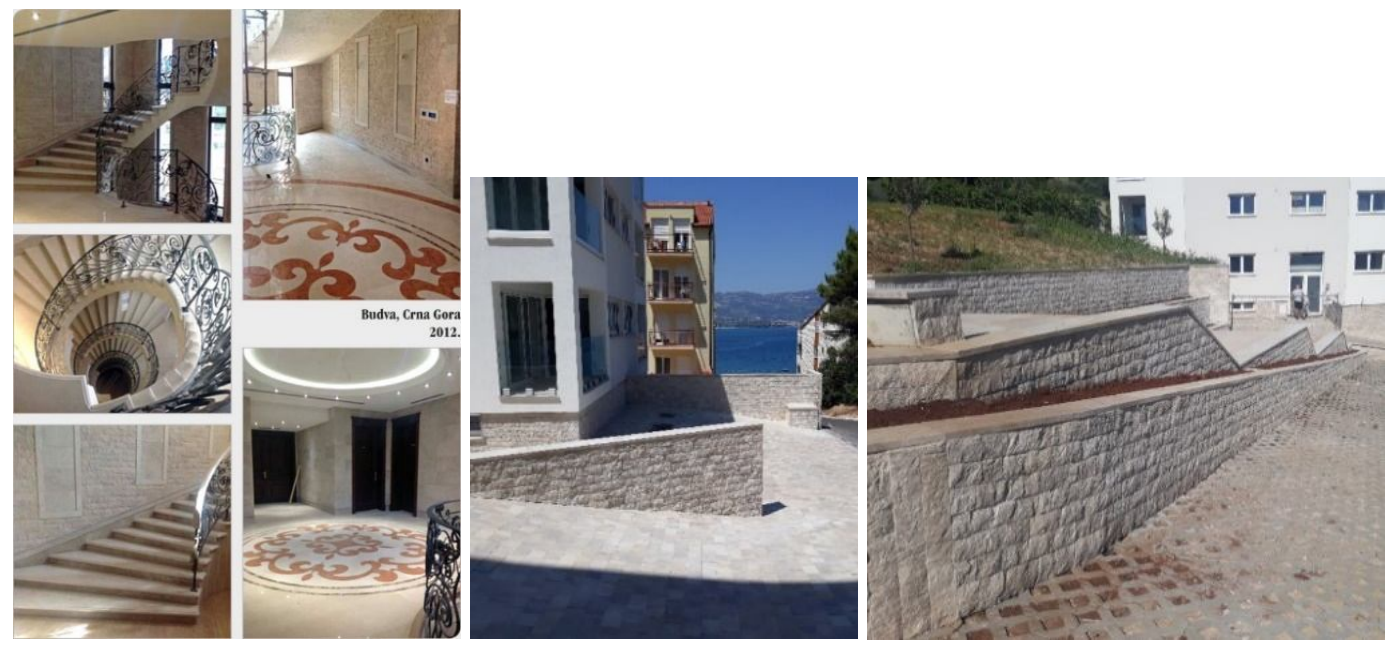

Figures 26-28. Application of "Rujan" stone in Villa Režević in Budva, Montenegro (2012; left); ${ }^{6}$ Cladding of external vertical elements of walls of buildings and the parterre part of the exterior of the apartment complex in Čiovo with "Rujan" stone (middle and right; photo:

A. Karačić, 2019) 6

One of the examples is the apartment complex in Čiovo, where it is applied in the exterior and interior with various examples of processing. The complete cladding of the common spaces of the apartment buildings, halls, staircase and garage space, and the parterre part of the complex, is made of this stone.

Particularly significant regional application of "Rujan" stone can be seen in the $€ 650$ million worth luxury resort "Portonovi" in Montenegro, in the town of Kumbor, Herceg Novi, the largest construction site in the region in the last decade. The project has been constructed in several phases since 2012, and Phase I was opened in the summer of 2018. Stone "Rujan" is used on almost every structure, as covering of facades, paths, roads, fountains, curbs, edging, docks, all the way to the frames around openings and wall copings.
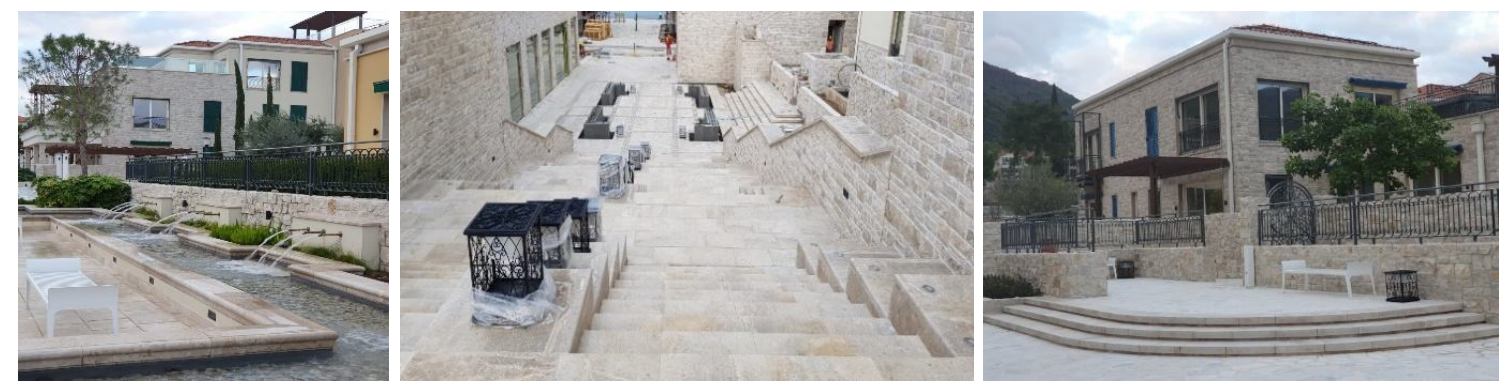

Figures 29-31. Project "Portonovi" - Fountain along the main promenade on the podium (left); Central stone staircase connecting the main promenade of the podium and the luxurious Marina (middle); Circular external staircase with segmental $L$ treads of the podium (right) (photo: A. Karačić, 2019) ${ }^{6}$ 
Šaravanja, K., Oreč, F., Karačić, A.

Application of Herzegovinian dolomite as dimension stone

\section{CONCLUSION}

The region of Herzegovina is rich in the dimension stone production resources, with a long tradition in production. The limestones of the commercial names "Osoje" and "Kljenak" from Posušje, "Gabro" from Jablanica and others are well known to everyone.

Dolomites are rarely used as dimension stone, such as the high-quality decorative dolomite with the commercial name "Sivac" from the bay Veselje on the island of Brač...

Some Herzegovinian dolomites can also be used as dimension stone, primarily due to the variety of colors and textures. Unfortunately, some of them have slightly poorer wear resistance and poorer antiskid resistance in wet conditions, which to some degree limits their applicability to horizontal traffic surfaces. For this reason, it is necessary to have a good knowledge of properties of each specific dolomite stone in order to properly apply it, and thus preserve its bearing capacity, durability and decorativeness in a particular environment.

In the last two decades, Herzegovinian dolomite with the commercial name "Rujan" has proven to be a high-quality decorative and protective vertical and horizontal cladding on numerous buildings in Herzegovina, and it was used on several regional architectural projects along the Adriatic coast.

\section{REFERENCES (in alphabetical order)}

1. Barić, Lj., Trubelja, F.: Minerali Bosne i Hercegovine Knjiga II - Nesilikati, „Svjetlost“, Sarajevo, 1984.

2. Bilbija, N., Matović, V.: Primenjena petrografija - svojstva i primene kamena, Drugo izdanje, „Građevinska knjiga“ d.o.o. Beograd, 2008.

3. Dragičević, I., Galić I., Vranjković, A., Farkaš, B., Galić, M.: Study on the reserves of dimension stone in the study area of "San", "Proin 21" d.o.o., Široki Brijeg, 2014.

4. Galić, I., Farkaš, B., Soldo, I., Vidić, D.: Mogućnosti eksploatacije i iskorištenja arhitektonsko-građevnog kamena u Hercegovini, "e-Zbornik" ellectronic collection of FCE UOM, Special issue, pp. 38-54, September 2018.

5. Galić, I.: Preliminary design for the exploitation of dimension stone in the exploitation field "San", "Proin 21" d.o.o., Široki Brijeg, 2019.

6. Karačić, A.: Architectural and structural values of stone 'Rujan' with special reference to its application in the Portonovi project (in Croatian), Graduation thesis, Faculty of Civil Engineering, University of Mostar, Mostar, 2020.

7. Marijanović, P., Galić, A.: Stone as the basic construction material of the church in Široki Brijeg and its symbolism; Scientific symposium: 100 Years of the Church in Široki Brijeg, Široki Brijeg 20 June 1905 - 20 June 2005, Proceedings, pp. 471-486, Franciscan monastery Siroki Brijeg, 2005.

8. Oreč, F., Šaravanja, K., Grbeša, I.: Architectural heritage of stone in the municipality of Posušje, with special reference to the condition of buildings made of miljevina (in Croatian), Proceedings from the $1^{\text {st }}$ International Symposium on Stone "Herzegovina the Country of Stone", pp. 155-172, Faculty of Civil Engineering, University of Mostar, Association "Sound of Stone" Posušje and "IGH" d.0.0. Mostar, Mostar, Book 1, No. 1, pp. 112-127, September 2013.

9. Plastić, T., Pulišelić, I., Bilopavlović, V., Knezović, Ž., Oreč, M.: Exploitation and processing of stone in Dalmatia and Herzegovina *Geological potentials, technologies, legal framework and environmental impact, Project "Stone", JU "RERA S.D.", Split, 2012.

10. Pudelko, F., Bilopavlović, V., Karačić, S.: O resursima kamena na području Hercegovine i Jugozapadne Bosne, „Rudarsko-geološki glasnik“, No. 4, Mostar, September 2000. 
Šaravanja, K., Oreč, F., Karačić, A.

Application of Herzegovinian dolomite as dimension stone

11. Strilić, M.: Optimization of the development of mining works in the exploitation field of dimension stone "San" (in Croatian), Graduation thesis, University of Zagreb, Faculty of Mining, Geology and Petroleum Engineering, Zagreb, 2019.

12. Šaravanja, K., Galić, A.: Resursi i svojstva građevnog kamena Hercegovine za obnovu graditeljske baštine / Stone's resources and properties in Herzegovina region for the reconstruction of the architectural heritage, Seminar on Restoration Principles in Počitelj, The Swedish Foundation for Cultural Heritage without Borders, Počitelj, September 2001.

13. Šaravanja, K., Marijanović, P.: Arhitektonsko-građevni i tehnički kamen na području Hercegovine, European Conference on Raw Materials and Coal - New Perspectives, Sarajevo, 2004.

14. Šaravanja, K., Šaravanja, D., Marić, T.: Analiza rezultata ispitivanja arhitektonskograđevnog kamena s područja Hercegovine i jugozapadne Bosne (Analysis of the test results of dimension stone from the area of Herzegovina and southwestern Bosnia), Proceedings of the $1^{\text {st }}$ International Symposium on Stone "Herzegovina - the Country of Stone", Book 1, No. 1, pp. 61-83, FCE UOM, Association "Sound of Stone" Posušje and "IGH" d.o.o. Mostar, Mostar, September 2013; "e-Zbornik" electronic collection of FCE UOM, No. 6, pp. 40-57, December 2013.

15. Šaravanja, K., Oreč, F.: Teaching manual - occupation: stone-cutter and stone-cutting technician, Association for Entrepreneurship and Business "LINK" Mostar, Mostar/Posušje, October 2018.

16. Šestanović, S.: Osnove geologije i petrografije - Primjena u građevinarstvu, „Školska knjiga“, Zagreb, 1986.

17. Tajder, M., Herak, M.: Petrologija i geologija, „Školska knjiga“, Zagreb, 1972.

18. Žderić, V., Šaravanja, K., Oreč, F.: Kamen za interijere s posebnim osvrtom na primjenu autohtonog hercegovačkog kamena (Stone for interiors with special emphasis on application of authentic natural stone from the Herzegovina region), "e-Zbornik" electronic collection of FCE UOM, No. 9, pp. 1-17, June 2015.

19. Zeljko, I., Zeljko, T.: Komercijalna i praktična podjela arhitektonsko-građevnog kamena, „Rudarsko-geološki glasnik“, No. 3, Mostar, 1999.

20. ....Report number MM/02-KA on the control test of properties of the dimension stone named "Rujan", quarry "Ivankovića Dolac", "IGH-Mostar" d.o.o., April 2000.

21. ...Report on testing No. 62-20-003/10, "IGH-Mostar" d.o.o., 12 May 2010. 